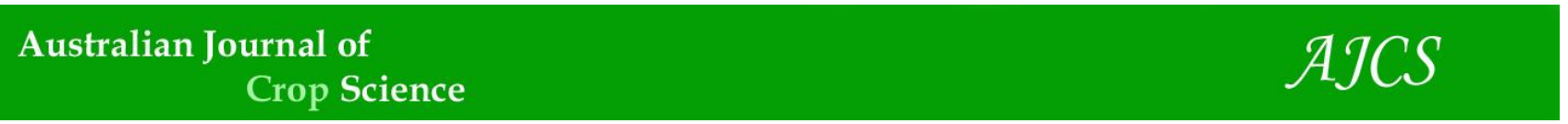

AJCS 15(02):251-259 (2021)

ISSN:1835-2707

doi: 10.21475/ajcs.21.15.02.p2932

\title{
Pre-sowing treatment of maize seeds by cold atmospheric plasma and pulsed electromagnetic fields: Effect on plant and kernels characteristics
}

\author{
Sofia Chanioti ${ }^{1}$, Nikolaos Katsenios ${ }^{2}$, Aspasia Efthimiadou ${ }^{2}$, Panagiota Stergiou ${ }^{1}$, Zacharoula-Maria \\ Xanthou ${ }^{1}$, Marianna Giannoglou ${ }^{1}$, Panagiotis Dimitrakellis ${ }^{3}$, Evangelos Gogolides ${ }^{3}$, George Katsaros ${ }^{1}$ \\ ${ }^{1}$ Institute of Technology of Agricultural Products, Hellenic Agricultural Organization-DEMETER, Sofokli Venizelou 1, \\ Lykovrissi 14123, Attica, Greece \\ ${ }^{2}$ Institute of Soil and Water Resources, Department of Soil Science of Athens, Hellenic Agricultural Organization- \\ DEMETER, Sofokli Venizelou 1, 14123, Lykovrissi, Attica, Greece \\ ${ }^{3}$ Institute of Nanoscience and Nanotechnology, NCSR “Demokritos”, Aghia Paraskevi 15341, Attiki, Greece
}

*Corresponding author: gkats@chemeng.ntua.gr

\begin{abstract}
The effect of cold atmospheric plasma (CAP) ( $45 \mathrm{kHz}$ sinusoidal AC high voltage at $6 \mathrm{kV}$ peak-to-peak for 5-15 min) and pulsed electromagnetic fields (PEMF) (amplitude $12.5 \mathrm{mT}$, repetitive frequency $3 \mathrm{~Hz}$ for $30 \mathrm{~min}$ ) as pre-sowing treatments was studied on the germination, physiology, yield and quality characteristics of maize hybrid seeds with high and low germination capability. The measurements conducted during the plant growth were the dry weight, chlorophyll content, photosynthetic rate, transpiration rate and stomatal conductance, while for the harvested kernels, the color, texture, sphericity, size, ash, total protein and total crude content were estimated. The results showed that CAP and PEMF pre-sowing treatments favored the growth and physiology of both maize plants improving their germination rate significantly. Their chlorophyll content, photosynthetic rate, transpiration rate, stomatal conductance as well as dry weight were also improved. Both CAP and PEMF treatments, resulted in maize yield increase by $18-25 \%$ and by $10-20 \%$ compared to untreated samples for the low and high germination capability seeds, respectively. With regards to the quality of the harvested corn grains, their total protein and crude fiber content obtained by CAP treatment for 15 min were significantly increased by $26 \%$ and $29 \%$ for low germination seeds and by $36 \%$ and $42 \%$ for high germination seeds, respectively, compared to untreated samples. The results indicate that either CAP or PEMF pre-sowing treatments could be used as alternative ameliorative tools in order to improve maize growth, productivity, yield and quality of the final products.
\end{abstract}

Keywords: cold atmospheric plasma, pulsed electromagnetic field, maize, growth, physiology, yield, quality characteristics, seed germination.

Abbreviations: CAP-Cold atmospheric plasma, PEMF-Pulsed Electromagnetic Fields, SDBD-Surface dielectric barrier discharge CRD- completely randomized design, DAS- days after sowing.

Introduction

Maize is a crop of significant global interest with a production of 1.12 billion metric tons in 2018-2019 (USDA, 2020). It comprises a significant ingredient for human nutrition since its kernels can be consumed as whole or grounded to flour or even used for extraction of oil exhibiting specific physicochemical properties. The increasing demands of food and other industrial sectors for improved corn yield and quality has led the agricultural science to new challenges. Since the cultivable area cannot be easily increased, a potential alternative approach could be the improvement of the crop yield achieved by higher seeds survival and more efficient growth of plants (de Groot et al., 2018; Jiang et al., 2014).

Conventionally, the improvement of seed germination, plant growth and productivity is performed either by physical (hot water, sunlight and ultraviolet light) or by chemical approaches (fertilizers, hormones, antibiotics, pesticides, herbicides and insecticides) (Li et al., 2016). However, these methods may produce chemical residuals, are expensive, time-consuming and inefficient for the reduction of harmful pathogens (Pérez-Pizá et al., 2019). Nowadays, farmers have a growing interest in applying alternative environmentalfriendly techniques (Sivachandiran and Khacef, 2017). Novel process technologies such as Cold Atmospheric Plasma (CAP) and Pulsed Electromagnetic Fields (PEMF) could potentially be used as pre-sowing treatments for the seeds, enhancing their growth rate (Sera et al., 2017; Bilalis et al., 2012).

Cold atmospheric plasma (CAP) is a weakly ionized gas, well acknowledged as the "fourth state of matter". Plasmas are generated by applying electrical energy in the form of DC, AC or high frequency (RF, MW) discharges and create a mixture of highly reactive species like ions, electrons, free radicals and UV photons. CAPs generated in air atmosphere are producing high densities of reactive oxygen and nitrogen species (RONS) that have recently enabled several agricultural applications (Thirumdas et al., 2017; Puac et al., 2018). CAP as pre-sowing treatment of seeds is an innovative technique, resulting in improved germination and 
plant growth as well as in promising anti-bactericidal and anti-fungicidal effect. Many studies have confirmed the potential of CAP pre-treatment on the germination, growth and yield of wheat seeds (Dobrin et al., 2015; Meng et al., 2017; Roy et al., 2018a; Jiang et al., 2014; Scholtz et al., 2019), cotton seeds (de Groot et al., 2018), watermelon seeds (Lotfy, 2017), oat seeds (Šerá et al., 2010), peanut seeds (Li et al., 2016), soybean seeds (Li et al., 2014; PérezPizá et al., 2019), oilseed rape seeds (Li et al., 2015), hemp seeds (Sera et al., 2017), maize seeds (Zahoranová et al., 2018), okra seeds (Kumar et al., 2019), wild asparagus seeds (Lo Porto et al., 2019) and other crops.

The role of magnetic field as a pre-sowing treatment on different plant species has been increasingly studied the last decades. The results indicate that different types of magnetic field, at different exposure times, -also depending on the device and the characteristics of the produced magnetic field- (Florez et al., 2007; Pietruszewski, 1996) can improve germination, plant growth and finally increase yield, a feature that affects positively the producers income and can lead to a more environmental friendly and sustainable agriculture.

Research has focused on various field crop species (cereals, oilseeds, pulses, cotton, sugar beet, etc.) due to their significant and worldwide cultivation. In some relative studies, magnetic field increased germination percentage of rice (Carbonell et al., 2000), wheat (Cakmak et al., 2010), maize (Florez et al., 2007), shoot length and root length of maize (Kataria et al., 2017), early stages growth of soybeans (Radhakrishnan and Kumari, 2012), chlorophyll content on maize plants (Racuciu et al., 2008; Bilalis et al., 2012) and maize physiology characteristics (Javed et al., 2011). Magnetic fields application has resulted in increased fresh and dry weight of maize kernels (Florez et al., 2007; Shabrangi et al., 2010) and wheat (Fischer et al., 2004). Similarly to CAP, magnetic field increased the yield of maize (Vashisth and Joshi, 2017), wheat (Pietruszewski and Kania, 2010) and cotton (Leelapriya et al., 2003) productions. Magnetic field potential mechanism for enhancing germination percentage and early stages growth could be the involvement of nitric oxide in the signal transduction of magnetic field (Patel et al., 2017). Moreover, magnetic field potentials as a pre-sowing treatment, could be attributed to increased $\alpha$-amylase activity at the third day after sowing (Katsenios et al., 2016), for treated seeds, affecting the germination percentage.

High percentage of seed germination is a factor of major importance for the successful establishment of crops and for a sustainable and high productivity and should be affected as minimally as possible by unfavorable environmental conditions in the period after the sowing (De Groot et al., 2018). Another factor for low germination percentages is the use of low vigor seeds. Physical methods like Pulsed Electromagnetic Fields (PEMF) could be used to increase seed germination of low vigor seeds in an ecologically friendly way (Araújo et al., 2016). This enhancement at seed vigor can be significantly useful for traditional seeds of local varieties of many plant species that exhibit low germination percentages.

Still there is limited knowledge on the effect of the application of CAP and PEMF on the nutritional value and the quality of the final plant products. The assessment of the responses of the corn plants grown from CAP or PEMF pretreated seeds in terms of germination, plant development and growth, corn yield as well as the quality properties of the harvested maize grains could provide valuable data to the agricultural community and contribute to the establishment of new farming practices.

The aim of this study was to investigate and compare the effects of CAP and PEMF technologies as pre-sowing treatments on the cultivation of two maize types of different germination capabilities in a certain ecological zone and soil conditions. The plant growth, physiology, yield as well as the quality characteristics of harvested corn kernels were evaluated.

\section{Results}

\section{Effect of novel technologies on maize seeds germination}

The CAP and PEMF pre-sowing treatment of both low and high germination seeds resulted in increase of germination percentage, compared to untreated samples. Statistically, the low germination seeds were different to control samples, while for the high germination seeds, the statistical analysis showed not significant differences compared to control (Figure 1). For the low germination seeds, CAP treatment for $10 \mathrm{~min}$ (CAP10) (55.83\%) had statistically significant differences compared to the control (41.67\%) and CAP5 (42.50\%) samples, while there were no statistically significant differences with the treatments of CAP15 (51.67\%) and PEMF (49.17\%). The results are in agreement with other results cited in the literature. A static magnetic field was used in maize and soybeans seeds showing increased germination values compared to untreated seeds, under non-saline and saline conditions (Kataria et al., 2017). In another study (Florez et al., 2007), magnetic field reduced time of maize germination and increased up to $25 \%$ its germination rate. Similar results were obtained for CAP, as well. CAP of $80 \mathrm{~W}$ improved seed germination of wheat by $6 \%$ (Jiang et al., 2014).

\section{Effect of novel technologies on maize physiology}

The pre-sowing treatment of the seeds gave statistically significant different results for the measurements of chlorophyll content at 52 DAS for the low germination capability seeds and at 72 DAS for the high germination capability (Table 3). For the low germination capability, all treatments (CAP5, CAP10, CAP15 and PEMF) gave statistically significant higher values compared to the control at 52 DAS. For the high germination capability, the treatments of CAP $(5,10$ and 15$)$ gave statistically significant higher values (68.30, 65.96 and 65.53, respectively) compared to the control (56.84), while there were no statistically significant differences with the treatment of PEMF (63.30). In a recent research, maize seeds that were exposed to static magnetic fields to $200 \mathrm{mT}$ for one hour, increased the values of chlorophyll content compared to the control by $0.5-29 \%$ (Vashisth and Joshi, 2017). Similar results are reported in a field experiment on wheat in China, where cold helium plasma increased chlorophyll content by $9.8 \%$ (Jiang et al., 2014).

The use of the pre-sowing treatments had a statistically significant effect on the photosynthetic rate at all measurements $(52,72$ and 88 DAS) for the low germination capability seeds, and for the 52 and 88 DAS of the high capability seeds (Table 3 ). For the low germination seeds, at all three measurements conducted, the treatments of CAP10, CAP15 and PEMF had statistically significant higher 
values than the Control and the CAP5 treatments. For the high germination capability seeds, at 52 DAS, the treatments of CAP10 (26.72 $\left.\mu \mathrm{mol} \mathrm{CO} \mathrm{m}^{-2} \mathrm{~s}^{-1}\right)$, CAP15 (27.95 $\mu \mathrm{mol} \mathrm{CO} \mathrm{m}^{-}$ $\left.{ }^{2} \mathrm{~s}^{-1}\right)$ and PEMF $\left(28.68 \mu \mathrm{mol} \mathrm{CO} \mathrm{CO}^{-2} \mathrm{~s}^{-1}\right)$ had statistically significant higher values compared to CAP5 $\left(23.65 \mu \mathrm{mol} \mathrm{CO} \mathrm{CO}_{2}\right.$ $\mathrm{m}^{-2} \mathrm{~s}^{-1}$ ), while CAP5 gave values statistically significant higher compared to control $\left(19.45 \mu \mathrm{mol} \mathrm{CO}_{2} \mathrm{~m}^{-2} \mathrm{~s}^{-1}\right)$. At the measurement of 88 DAS, the treatments of CAP10 (37.79 $\left.\mu \mathrm{mol} \mathrm{CO}_{2} \mathrm{~m}^{-2} \mathrm{~s}^{-1}\right)$, CAP15 $\left(37.35 \mu \mathrm{mol} \mathrm{CO} \mathrm{m}^{-2} \mathrm{~s}^{-1}\right)$ and PEMF $\left(37.53 \mu \mathrm{mol} \mathrm{CO} \mathrm{Cm}^{-2} \mathrm{~s}^{-1}\right)$ had statistically significant higher values compared to CAP5 (31.62 $\left.\mu \mathrm{mol} \mathrm{CO}_{2} \mathrm{~m}^{-2} \mathrm{~s}^{-1}\right)$ and control $\left(30.91 \mu \mathrm{mol} \mathrm{CO} \mathrm{m}^{-2} \mathrm{~s}^{-1}\right)$.

For the transpiration rate measurements, the pre-sowing treatments gave statistically significant differences only for the low germination capability seeds, at 52 and 72 DAS. At $52 \mathrm{DAS}$, the treatment of PEMF $\left(3.22 \mathrm{mmol} \mathrm{H}_{2} \mathrm{O} \mathrm{m}^{-2} \mathrm{~s}^{-1}\right)$ gave the highest values with statistically significant differences compared to the CAP5 (2.49 $\left.\mathrm{mmol} \mathrm{H}_{2} \mathrm{O} \mathrm{m} \mathrm{m}^{-1}\right)$ and the

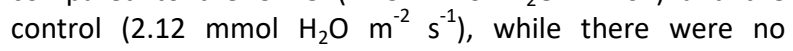
statistically significant differences with CAP10 $(2.77 \mathrm{mmol}$ $\left.\mathrm{H}_{2} \mathrm{O} \mathrm{m}^{-2} \mathrm{~s}^{-1}\right)$ and CAP15 $\left(2.82 \mathrm{mmol} \mathrm{H}_{2} \mathrm{O} \mathrm{m}^{-2} \mathrm{~s}^{-1}\right)$. At 72 DAS, CAP15 (5.65 mmol $\mathrm{H}_{2} \mathrm{O} \mathrm{m}^{-2} \mathrm{~s}^{-1}$ ) and PEMF ( $5.48 \mathrm{mmol} \mathrm{H}_{2} \mathrm{O} \mathrm{m}^{-}$ $\left.2 s^{-1}\right)$ gave the highest values with statistically significant differences compared to the control $\left(3.87 \mathrm{mmol} \mathrm{H}_{2} \mathrm{O} \mathrm{m}^{-2} \mathrm{~s}^{-1}\right.$ ) (Table 4).

For the measurement of stomatal conductance, the presowing treatments gave statistically significant differences at 52 and 72 DAS for both low and high germination capability seeds (Table 4). For the low germination capability seeds, the pre-sowing treatments gave values statistically significant higher compared to the control at 52 DAS. At 72 DAS, CAP15 $\left(0.20 \mathrm{~mol} \mathrm{~m}^{-2} \mathrm{~s}^{-1}\right)$ and PEMF $\left(0.20 \mathrm{~mol} \mathrm{~m}^{-2} \mathrm{~s}^{-1}\right)$ had statistically significant differences compared to the control $\left(0.15 \mathrm{~mol} \mathrm{~m}^{-2} \mathrm{~s}^{-1}\right)$, although there were no statistically significant differences with the other CAP treatments. For the high germination capability seeds, at 52 DAS measurement, PEMF $\left(0.17 \mathrm{~mol} \mathrm{~m}^{-2} \mathrm{~s}^{-1}\right)$ had statistically significant differences compared to the control $\left(0.12 \mathrm{~mol} \mathrm{~m}^{-2}\right.$ $\left.\mathrm{s}^{-1}\right)$ and the CAP5 $\left(0.14 \mathrm{~mol} \mathrm{~m}^{-2} \mathrm{~s}^{-1}\right)$, although there were no statistically significant differences compared to CAP10 (0.15 $\left.\mathrm{mol} \mathrm{m} \mathrm{s}^{-1}\right)$ and CAP15 $\left(0.16 \mathrm{~mol} \mathrm{~m}^{-2} \mathrm{~s}^{-1}\right)$. At 72 DAS, all the pre-sowing treatments gave values statistically significant higher compared to the control. Compared to the literature, in a three-year field experiment of two durum wheat varieties, the use of PEMF increased photosynthetic rate, transpiration rate and stomatal conductance compared to the control (Katsenios et al., 2016). The increased chlorophyll content of maize plants of pre-sowed treated seeds, resulted in higher values at the physiology measurements and all this enhancement resulted in increased yield.

\section{Effect of novel technologies on maize dry weight and yield}

For the measurement of dry weight, the pre-sowing treatments gave statistically significant differences at 72 and 88 DAS, for both low and high germination capability seeds (Table 5). For the low germination seeds, the treatments of CAP10, CAP15 and PEMF gave statistically significant higher values compared to the CAP5 and control of 72 and 88 DAS. For the high germination capability, at the second measurement, CAP10 (599 g), CAP15 (596 g) and PEMF (623 g) were statistically significantly higher than the value of the CAP5 $(544 \mathrm{~g})$ that was statistically significantly higher compared to control (498 g). At $88 \mathrm{DAS}$, all the pre-sowing treatments gave values statistically significant higher compared to the control. Vashisth and Joshi (2017), in a maize field experiment that was established in India, found that the treatment of magnetic field of $200 \mathrm{mT}$ for $1 \mathrm{~h}$ increased dry weight per plant by $24-70 \%$ compared to the untreated seeds. Li et al. (2014) reported that cold plasma, and specifically the treatment of $80 \mathrm{~W}$ increased shoot weight of soybean by $21.95 \%$ compared to the control.

The pre-sowing treatment on maize seeds affected statistically significantly the yield per plant both at the low and high germination capability seeds (Table 5). For the low germination capability seeds, the pre-sowing treatments CAP5 (245 g), CAP10 (261 g), CAP15 (237 g) and PEMF (253 g) gave statistically significant higher values compared to the control (196 g). For the high germination capability seeds, CAP10 (238 g), CAP15 (259 g) and PEMF (255 g) had statistically significant differences compared to the control $(207 \mathrm{~g})$, while there were no statistically significant differences with the treatment of CAP5 $(231 \mathrm{~g})$. In a wheat experiment, cold plasma treatment by $6 \mathrm{~min}$, increased grain yield by approximately $20 \%$ (Roy et al., 2018a), while in a peanut cultivation cold plasma treatment of $120 \mathrm{~W}$ improved yield by $10 \%$ compared to the control (Li et al., 2016). Magnetic field treatment on seeds of spring wheat cultivation increased yield by $12.5-14.5 \%$ compared to the control (Pietruszewski and Kania, 2010). Similar results have been found in a pot experiment of common corn and sweet corn cultivations, where magnetic field treatments increased grain yield in both corn types compared to non-treated seeds (Bilalis et al., 2012).

\section{Effect of novel technologies on physical properties of the harvested corn seeds}

The effect of different pre-sowing treatments of maize seeds with low and high germination capability on the color parameters, the texture, the sphericity and the size of the harvested corn seeds, respectively, are presented in Table 6 . Concerning the maize seeds with low germination capability, the different pre-sowing treatment affected significantly the lightness $(L)$ and the texture of the corn seeds $(p<0.05)$. In particular, CAP pre-sowing treatment of the maize seeds for 5 and 15 min resulted in corn seeds with higher lightness values ( 76.18 and 77.08 for CAP5 and CAP15, respectively) than those obtained by the other treatments. The hardness of corn seeds was positively affected by CAP5 $(24.77 \mathrm{~N})$ and CAP10 $(24.71 \mathrm{~N})$ pre-sowing treatments compared to all other treatments, except for PEMF $(22.99 \mathrm{~N})$ treatment $(p<0.05)$.

As far as the maize seeds with high germination capability is concerned, the size of the harvested corn seeds obtained by CAP pre-sowing treatment for $15 \mathrm{~min}(153.39 \mathrm{~mm})$ was significantly higher than the one obtained by the other treatments, except for CAP treatment for $10 \mathrm{~min}$ (143.86 $\mathrm{mm}$ ). The PEMF pre-sowing treatment of maize seeds resulted in corn grains with the smallest geometric mean diameter (size) (113.18 g) from all the harvested grains.

The physical properties of corn grains including color parameters $(L, a, b)$, texture, sphericity and size from seeds of both germination capabilities, were found to be in accordance with those reported by other authors for maize grains (Yenge et al., 2018; Atere et al., 2016; Alan et al., 2014). It should be noticed that the application of presowing treatments such as CAP and PEMF, improved significantly the quality characteristics of corn grains including 
Table 1. Physical and chemical properties of the soil where the hybrids were sowed.

\begin{tabular}{|c|c|}
\hline Parameters & Values \\
\hline Sand (\%) & 36 \\
\hline Silt (\%) & 28 \\
\hline Clay (\%) & 36 \\
\hline Soil Texture & Clay Loam \\
\hline $\mathrm{pH}$ & 7.5 \\
\hline Saturation percentage (\%) & 60 \\
\hline Electrical Conductivity (ms/cm) & 1.57 \\
\hline Total salts (\%) & 0.06 \\
\hline Organic Matter (\%) & 5.5 \\
\hline Total Nitrogen $(\mathrm{mg} / \mathrm{g})$ & 2.8 \\
\hline $\mathrm{CaCO}_{3}(\%)$ & 14 \\
\hline Available $\mathrm{K}(\mathrm{cmol}+/ \mathrm{kg})$ & 1.1 \\
\hline Available $\mathrm{Ca}(\mathrm{cmol}+/ \mathrm{kg})$ & 27 \\
\hline Available $\mathrm{Mg}(\mathrm{cmol}+/ \mathrm{kg})$ & 7.3 \\
\hline Available P (mg/kg) & 99 \\
\hline Available Fe (mg/kg) & 22 \\
\hline Available $\mathrm{Cu}(\mathrm{mg} / \mathrm{kg})$ & 4.1 \\
\hline Available Zn (mg/kg) & 8.2 \\
\hline Available $\mathrm{Mn}(\mathrm{mg} / \mathrm{kg})$ & 22 \\
\hline Available B $(\mathrm{mg} / \mathrm{kg})$ & 0.9 \\
\hline
\end{tabular}

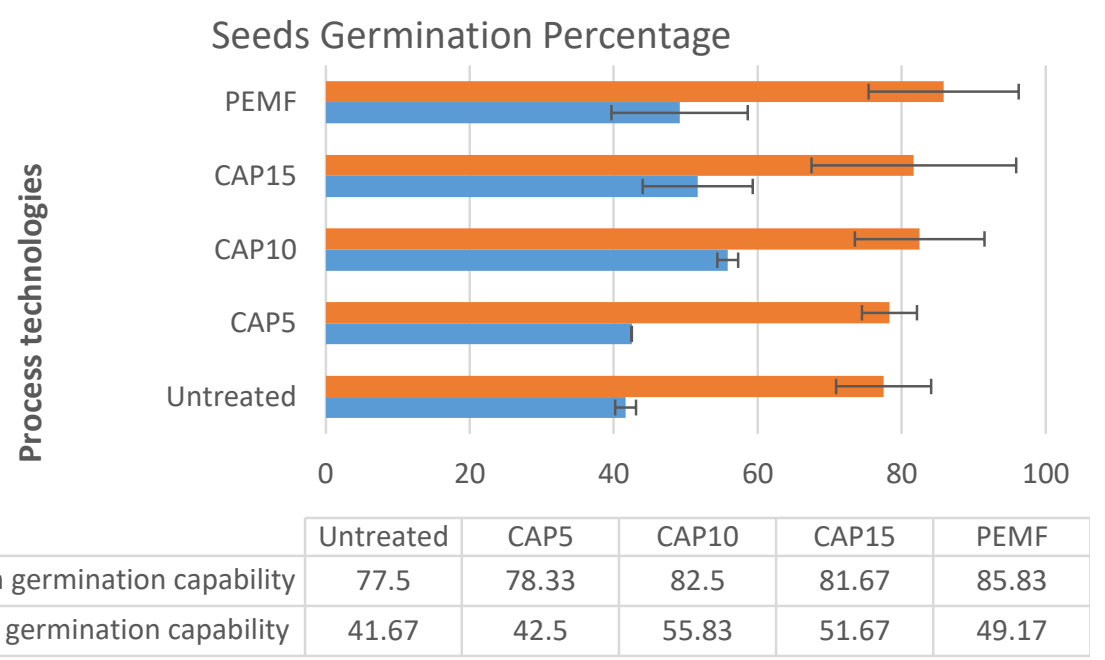

Fig 1. Effect of cold atmospheric plasma and pulsed electromagnetic field at germination percentage of maize plants derived from seeds with low (A) and high (B) germination capability. CAP5, CAP10, CAP15: Cold atmospheric Plasma pre-sowing treatment of the maize seeds for 5, 10 and $15 \mathrm{~min}$, respectively. PEMF: Pulsed electromagnetic field pre-sowing treatment of the maize seeds for 15 min. Mean value of three replicates \pm standard deviation.

Table 2. Mean maximum, mean minimum, mean temperature and rainfall values recorded for each month during the experimental period.

\begin{tabular}{lllll}
\hline & Tempereture & & & Precipitation \\
\hline & Mean $\operatorname{Max}\left({ }^{\circ} \mathrm{C}\right)$ & Mean $\operatorname{Min}\left({ }^{\circ} \mathrm{C}\right)$ & Mean $\left({ }^{\circ} \mathrm{C}\right)$ & Total $(\mathrm{mm})$ \\
April & 19.3 & 9.5 & 14.4 & 62.8 \\
May & 25.2 & 13.2 & 19.3 & 6.4 \\
June & 31.3 & 20.2 & 26.1 & 0.0 \\
July & 32.6 & 20.8 & 26.8 & 4.6 \\
August & 33.0 & 22.3 & 27.8 & 0.0 \\
\hline
\end{tabular}


Table 3. Effect of cold atmospheric plasma and pulsed electromagnetic field seeds pre-treatment on chlorophyll content and photosynthetic rate of maize plants derived from seeds with low $(A)$ and high (B) germination capability.

\begin{tabular}{|c|c|c|c|c|c|c|}
\hline \multirow{2}{*}{ Treatment } & \multicolumn{3}{|c|}{ Chlorophyll content (SPAD values) } & \multicolumn{3}{|c|}{ Photosynthetic rate $\left(\mu \mathrm{mol} \mathrm{CO}{ }_{2} \mathrm{~m}^{-2} \mathrm{~s}^{-1}\right)$} \\
\hline & 52 DAS & 72 DAS & $88 \mathrm{DAS}$ & 52 DAS & 72 DAS & 88 DAS \\
\hline \multicolumn{7}{|c|}{ A. Low germination capability } \\
\hline Untreated & $47.10 \pm 4.13^{b}$ & $56.00 \pm 7.72^{\text {n.s. }}$ & $57.23 \pm 1.37^{\text {n.s. }}$ & $21.19 \pm 1.55^{b}$ & $28.18 \pm 1.59^{b}$ & $28.65 \pm 1.39^{b}$ \\
\hline CAP5 & $53.93 \pm 1.90^{\mathrm{a}}$ & $62.66 \pm 3.01^{\text {n.s. }}$ & $57.43 \pm 11.91^{\text {n.s. }}$ & $21.22 \pm 2.06^{\mathrm{b}}$ & $28.46 \pm 2.04^{b}$ & $32.28 \pm 4.21^{b}$ \\
\hline CAP10 & $53.20 \pm 2.09^{\mathrm{a}}$ & $58.60 \pm 4.59^{\text {n.s. }}$ & $64.73 \pm 2.35^{\text {n.s. }}$ & $26.61 \pm 0.86^{a}$ & $33.03 \pm 2.65^{\mathrm{a}}$ & $34.36 \pm 1.65^{\mathrm{a}}$ \\
\hline CAP15 & $54.76 \pm 2.77^{\mathrm{a}}$ & $60.57 \pm 3.13^{\text {n.s. }}$ & $63.50 \pm 5.30^{\text {n.s. }}$ & $26.94 \pm 1.48^{\mathrm{a}}$ & $35.34 \pm 1.65^{\mathrm{a}}$ & $37.24 \pm 2.46^{\mathrm{a}}$ \\
\hline PEMF & $53.40 \pm 1.54^{\mathrm{a}}$ & $56.93 \pm 7.26^{\text {n.s. }}$ & $62.63 \pm 3.82^{\text {n.s. }}$ & $27.08 \pm 1.52^{\mathrm{a}}$ & $34.01 \pm 1.58^{\mathrm{a}}$ & $35.15 \pm 2.51^{a}$ \\
\hline \multicolumn{7}{|c|}{ B. High germination capability } \\
\hline Untreated & $48.20 \pm 2.88^{\text {n.s. }}$ & $56.84 \pm 1.77^{b}$ & $58.26 \pm 2.05^{\text {n.s. }}$ & $19.45 \pm 0.63^{c}$ & $32.12 \pm 1.30^{\text {n.s. }}$ & $30.91 \pm 2.68^{b}$ \\
\hline CAP5 & $49.23 \pm 3.03^{\text {n.s. }}$ & $68.30 \pm 2.92^{\mathrm{a}}$ & $59.73 \pm 4.52^{\text {n.s. }}$ & $23.65 \pm 1.05^{b}$ & $34.88 \pm 3.53^{\text {n.s. }}$ & $31.62 \pm 4.11^{b}$ \\
\hline CAP10 & $57.26 \pm 6.71^{\text {n.s. }}$ & $65.96 \pm 6.11^{\mathrm{a}}$ & $65.33 \pm 2.68^{\text {n.s. }}$ & $26.72 \pm 0.89^{a}$ & $34.74 \pm 0.41^{\text {n.s. }}$ & $37.79 \pm 2.59^{\mathrm{a}}$ \\
\hline CAP15 & $51.53 \pm 3.28^{\text {n.s. }}$ & $65.53 \pm 4.75^{\mathrm{a}}$ & $64.20 \pm 1.24^{\text {n.s. }}$ & $27.95 \pm 2.08^{a}$ & $35.84 \pm 1.95^{\text {n.s. }}$ & $37.35 \pm 2.13^{\mathrm{a}}$ \\
\hline PEMF & $51.63 \pm 1.92^{\text {n.s. }}$ & $63.30 \pm 2.26^{\mathrm{ab}}$ & $63.83 \pm 4.26^{\text {n.s. }}$ & $28.68 \pm 1.14^{\mathrm{a}}$ & $36.87 \pm 1.50^{\text {n.s. }}$ & $37.53 \pm 2.62^{\mathrm{a}}$ \\
\hline
\end{tabular}

CAP5, CAP10, CAP15: Cold atmospheric Plasma pre-sowing treatment of the maize seeds for 5, 10 and 15 min, respectively.

PEMF: Pulsed electromagnetic field pre-sowing treatment of the maize seeds for $15 \mathrm{~min}$. Mean value of three replicates \pm standard deviation. Values with different superscripts $(a, b, c)$ in the same column were significantly different as shown by Duncan's multiple range test.

n.s. : not significant

Table 4. Effect of cold atmospheric plasma and pulsed electromagnetic field seeds pre-treatment on transpiration rate and stomatal conductance of maize plants derived from seeds with low (A) and high (B) germination capability.

\begin{tabular}{|c|c|c|c|c|c|c|}
\hline \multirow{2}{*}{ Treatment } & \multicolumn{3}{|c|}{ Transpiration rate $\left(\mathrm{mmol} \mathrm{H}_{2} \mathrm{O} \mathrm{m}^{-2} \mathrm{~s}^{-1}\right)$} & \multicolumn{3}{|c|}{ Stomatal conductance $\left(\mathrm{mol} \mathrm{m}^{-2} \mathrm{~s}^{-1}\right)$} \\
\hline & 52 DAS & 72 DAS & 88 DAS & 52 DAS & 72 DAS & 88 DAS \\
\hline \multicolumn{7}{|c|}{ A. Low germination capability } \\
\hline Untreated & $2.12 \pm 0.28^{c}$ & $3.87 \pm 0.25^{b}$ & $2.98 \pm 0.38^{\text {n.s. }}$ & $0.08 \pm 0.02^{b}$ & $0.15 \pm 0.02^{b}$ & $0.21 \pm 0.03^{\text {n.s. }}$ \\
\hline CAP5 & $2.49 \pm 0.13^{\mathrm{bc}}$ & $4.97 \pm 1.22^{\mathrm{ab}}$ & $3.54 \pm 0.26^{\text {n.s. }}$ & $0.13 \pm 0.02^{\mathrm{a}}$ & $0.18 \pm 0.02^{\mathrm{ab}}$ & $0.25 \pm 0.02^{\text {n.s. }}$ \\
\hline CAP10 & $2.77 \pm 0.28^{\mathrm{ab}}$ & $4.88 \pm 0.34^{\mathrm{ab}}$ & $3.69 \pm 0.34^{\text {n.s. }}$ & $0.16 \pm 0.02^{\mathrm{a}}$ & $0.20 \pm 0.05^{\mathrm{ab}}$ & $0.27 \pm 0.01^{\text {n.s. }}$ \\
\hline CAP15 & $2.82 \pm 0.22^{\mathrm{ab}}$ & $5.65 \pm 0.16^{\mathrm{a}}$ & $3.77 \pm 0.27^{\text {n.s. }}$ & $0.14 \pm 0.01^{\mathrm{a}}$ & $0.20 \pm 0.02^{\mathrm{a}}$ & $0.32 \pm 0.09^{\text {n.s. }}$ \\
\hline PEMF & $3.22 \pm 0.47^{\mathrm{a}}$ & $5.48 \pm 0.23^{\mathrm{a}}$ & $3.53 \pm 0.39^{\text {n.s. }}$ & $0.14 \pm 0.02^{\mathrm{a}}$ & $0.23 \pm 0.02^{\mathrm{a}}$ & $0.23 \pm 0.02^{\text {n.s. }}$ \\
\hline \multicolumn{7}{|c|}{ B. High germination capability } \\
\hline Untreated & $2.31 \pm 0.11^{\text {n.s. }}$ & $5.41 \pm 0.56^{\text {n.s. }}$ & $3.54 \pm 0.28^{\text {n.s. }}$ & $0.12 \pm 0.02^{c}$ & $0.21 \pm 0.02^{b}$ & $0.22 \pm 0.02^{\text {n.s. }}$ \\
\hline CAP5 & $2.81 \pm 0.31^{\text {n.s. }}$ & $5.49 \pm 1.55^{\text {n.s. }}$ & $3.88 \pm 0.15^{\text {n.s. }}$ & $0.14 \pm 0.01^{b c}$ & $0.24 \pm 0.01^{\mathrm{a}}$ & $0.25 \pm 0.05^{\text {n.s. }}$ \\
\hline CAP10 & $2.65 \pm 0.19^{\text {n.s. }}$ & $5.54 \pm 0.56^{\text {n.s. }}$ & $3.88 \pm 0.60^{\text {n.s. }}$ & $0.15 \pm 0.02^{\mathrm{ab}}$ & $0.24 \pm 0.01^{\mathrm{a}}$ & $0.28 \pm 0.05^{\text {n.s. }}$ \\
\hline CAP15 & $2.78 \pm 0.24^{\text {n.s. }}$ & $5.56 \pm 0.46^{\text {n.s. }}$ & $3.93 \pm 0.18^{\text {n.s. }}$ & $0.16 \pm 0.01^{\mathrm{ab}}$ & $0.24 \pm 0.02^{\mathrm{a}}$ & $0.24 \pm 0.03^{\text {n.s. }}$ \\
\hline PEMF & $2.84 \pm 0.14^{\text {n.s. }}$ & $5.43 \pm 0.03^{\text {n.s. }}$ & $4.21 \pm 0.60^{\text {n.s. }}$ & $0.17 \pm 0.03^{\mathrm{a}}$ & $0.23 \pm 0.01^{\mathrm{a}}$ & $0.29 \pm 0.02^{\text {n.s. }}$ \\
\hline
\end{tabular}

CAP5, CAP10, CAP15: Cold atmospheric Plasma pre-sowing treatment of the maize seeds for 5, 10 and 15 min, respectively.

PMF: Pulsed electromagnetic field pre-sowing treatment of the maize seeds for 15 min. Mean value of three replicates \pm standard deviation. Values with different superscripts $(a, b, c)$ in the same column were significantly different as shown by Duncan's multiple range test. ${ }^{\text {n.s. }}$ : not significant

Table 5. Effect of cold atmospheric plasma and pulsed electromagnetic field seeds pre-treatment on dry weight and yield of maize plants derived from seeds with low (A) and high (B) germination capability.

\begin{tabular}{|c|c|c|c|c|}
\hline \multirow{2}{*}{ Treatment } & \multicolumn{3}{|c|}{ Dry Weight (g per plant) } & \multirow[t]{2}{*}{ Yield (g per plant) } \\
\hline & 52 DAS & 72 DAS & 88 DAS & \\
\hline Untreated & $186 \pm 11^{\text {n.s. }}$ & $507 \pm 14^{b}$ & $533 \pm 16^{b}$ & $196 \pm 23^{b}$ \\
\hline CAP5 & $211 \pm 10^{\text {n.s. }}$ & $523 \pm 24^{b}$ & $555 \pm 26^{b}$ & $245 \pm 10^{a}$ \\
\hline CAP10 & $195 \pm 08^{\text {n.s. }}$ & $598 \pm 30^{\mathrm{a}}$ & $620 \pm 41^{a}$ & $261 \pm 15^{a}$ \\
\hline CAP15 & $201 \pm 06^{\text {n.s. }}$ & $593 \pm 25^{a}$ & $621 \pm 07^{a}$ & $237 \pm 09^{a}$ \\
\hline PEMF & $200 \pm 16^{\text {n.s. }}$ & $612 \pm 20^{\mathrm{a}}$ & $650 \pm 37^{a}$ & $253 \pm 04^{a}$ \\
\hline \multicolumn{5}{|c|}{ B. High germination capability } \\
\hline Untreated & $176 \pm 12^{\text {n.s. }}$ & $498 \pm 16^{c}$ & $526 \pm 24^{b}$ & $207 \pm 17^{b}$ \\
\hline CAP5 & $195 \pm 09^{\text {n.s. }}$ & $544 \pm 26^{\mathrm{b}}$ & $593 \pm 26^{a}$ & $231 \pm 19^{\mathrm{ab}}$ \\
\hline CAP10 & $194 \pm 17^{\text {n.s. }}$ & $599 \pm 22^{a}$ & $626 \pm 21^{a}$ & $238 \pm 15^{a}$ \\
\hline CAP15 & $199 \pm 16^{\text {n.s. }}$ & $596 \pm 16^{a}$ & $627 \pm 25^{a}$ & $259 \pm 17^{a}$ \\
\hline PEMF & $210 \pm 15^{\text {n.s. }}$ & $623 \pm 24^{a}$ & $624 \pm 23^{a}$ & $255 \pm 11^{a}$ \\
\hline
\end{tabular}

CAP5, CAP10, CAP15: Cold atmospheric Plasma pre-sowing treatment of the maize seeds for 5, 10 and 15 min, respectively.

PMF: Pulsed electromagnetic field pre-sowing treatment of the maize seeds for $15 \mathrm{~min}$. Mean value of three replicates \pm standard deviation.Values with different superscripts $(a, b, c)$ in the same column were significantly different as shown by Duncan's multiple range test. ${ }^{\text {n.s. }}$ : not significant. 
Table 6. Color parameters, texture, sphericity and size of corn seeds derived from different pre-sowing treatments of maize seeds with low (A) and high (B) germination capability, respectively.

\begin{tabular}{|c|c|c|c|c|c|c|}
\hline \multirow{2}{*}{ Treatment } & \multicolumn{3}{|c|}{ Color parameters } & \multirow{2}{*}{$\begin{array}{l}\text { Texture } \\
\text { (N) }\end{array}$} & \multirow{2}{*}{ Sphericity } & \multirow{2}{*}{$\begin{array}{l}\text { Size } \\
(\mathrm{mm})\end{array}$} \\
\hline & $\mathrm{L}$ & $\mathrm{a}$ & $\mathrm{b}$ & & & \\
\hline \multicolumn{7}{|c|}{ A. Low germination capability } \\
\hline Untreated & $74.56 \pm 1.58^{\mathrm{abc}}$ & $9.14 \pm 0.16^{\text {n.s. }}$ & $39.87 \pm 1.19$ & $10.96 \pm 0.19^{c}$ & $0.666 \pm 0.003^{\text {n.s. }}$ & $7.602 \pm 0.130^{\text {n.s. }}$ \\
\hline CAP5 & $76.18 \pm 1.76^{\mathrm{ab}}$ & $8.45 \pm 0.42^{\text {n.s. }}$ & $48.06 \pm 1.25$ & $24.77 \pm 0.15^{\mathrm{a}}$ & $0.658 \pm 0.004^{\text {n.s. }}$ & $7.203 \pm 0.129^{\text {n.s. }}$ \\
\hline CAP10 & $73.88 \pm 0.41^{b c}$ & $10.76 \pm 0.56^{\text {n.s. }}$ & $50.80 \pm 0.85$ & $24.71 \pm 0.41^{\mathrm{a}}$ & $0.654 \pm 0.032^{\text {n.s. }}$ & $7.288 \pm 0.167^{\text {n.s. }}$ \\
\hline CAP15 & $77.04 \pm 1.49^{\mathrm{a}}$ & $8.22 \pm 0.55^{\text {n.s. }}$ & $43.11 \pm 1.80$ & $20.01 \pm 1.29^{b}$ & $0.682 \pm 0.023^{\text {n.s. }}$ & $7.137 \pm 0.254^{\text {n.s. }}$ \\
\hline PEMF & $73.18 \pm 0.61^{\mathrm{c}}$ & $9.80 \pm 0.61^{\text {n.s. }}$ & $49.23 \pm 1.42$ & $22.99 \pm 1.40^{\mathrm{ab}}$ & $0.652 \pm 0.030^{\text {n.s. }}$ & $7.584 \pm 0.199^{\text {n.s. }}$ \\
\hline \multicolumn{7}{|c|}{ B. High germination capability } \\
\hline Untreated & $76.20 \pm 1.17^{\text {n.s. }}$ & $9.38 \pm 0.10^{\text {n.s. }}$ & $47.85 \pm 1.97^{\text {n.s. }}$ & $20.26 \pm 1.36^{\text {n.s. }}$ & $0.697 \pm 0.041^{\text {n.s. }}$ & $7.270 \pm 0.120^{b}$ \\
\hline CAP5 & $75.19 \pm 1.75^{\text {n.s. }}$ & $8.01 \pm 0.62^{\text {n.s. }}$ & $48.04 \pm 1.45^{\text {n.s. }}$ & $16.36 \pm 1.98^{\text {n.s. }}$ & $0.657 \pm 0.042^{\text {n.s. }}$ & $7.608 \pm 0.125^{\mathrm{ab}}$ \\
\hline CAP10 & $73.12 \pm 1.80^{\text {n.s. }}$ & $10.32 \pm 1.03^{\text {n.s. }}$ & $51.49 \pm 1.12^{\text {n.s. }}$ & $11.16 \pm 1.19^{\text {n.s. }}$ & $0.670 \pm 0.013^{\text {n.s. }}$ & $7.555 \pm 0.115^{\mathrm{ab}}$ \\
\hline CAP15 & $73.94 \pm 1.00^{\text {n.s. }}$ & $9.53 \pm 0.87^{\text {n.s. }}$ & $47.89 \pm 1.60^{\text {n.s. }}$ & $13.86 \pm 1.01^{\text {n.s. }}$ & $0.618 \pm 0.017^{\text {n.s. }}$ & $7.661 \pm 0.079^{a}$ \\
\hline PEMF & $76.41 \pm 1.05^{\text {n.s. }}$ & $8.49 \pm 1.22^{\text {n.s. }}$ & $48.94 \pm 1.02^{\text {n.s. }}$ & $20.30 \pm 1.25^{\text {n.s. }}$ & $0.659 \pm 0.019^{\text {n.s. }}$ & $6.877 \pm 0.068^{c}$ \\
\hline
\end{tabular}

CAP5, CAP10, CAP15: Cold atmospheric Plasma pre-sowing treatment of the maize seeds for 5, 10 and 15 min, respectively. PEMF: Pulsed electromagnetic field pre-sowing treatment of the maize seeds for $15 \mathrm{~min}$. Mean value of three replicates \pm standard deviation. Values with different superscripts $(a, b, c)$ in the same column were significantly different as shown by Duncan's multiple range test.

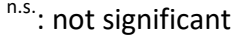

Table 7. Moisture (\%), ash (\%), total protein (\%) and total fibers (\%) content of corn flours derived from different pre-sowing treatments of maize seeds with low (A) and high (B) germination capability, respectively.

\begin{tabular}{|c|c|c|c|c|}
\hline Treatment & Moisture (\%) & Ash (\%) & Total Protein (\%) & Total fibers (\%) \\
\hline \multicolumn{5}{|c|}{ A. Low germination capability } \\
\hline Untreated & $8.54 \pm 0.36^{\text {n.s. }}$ & $1.29 \pm 0.02^{\text {n.s. }}$ & $9.22 \pm 0.17^{b c}$ & $2.67 \pm 0.19^{c}$ \\
\hline CAP5 & $7.91 \pm 0.31^{\text {n.s. }}$ & $2.09 \pm 0.04^{\text {n.s. }}$ & $8.87 \pm 0.13^{c}$ & $2.70 \pm 0.13^{c}$ \\
\hline CAP10 & $8.60 \pm 0.12^{\text {n.s. }}$ & $1.87 \pm 0.04^{\text {n.s. }}$ & $8.55 \pm 0.14^{c}$ & $3.56 \pm 0.12^{\mathrm{ab}}$ \\
\hline CAP15 & $8.03 \pm 0.38^{\text {n.s. }}$ & $1.92 \pm 0.07^{\text {n.s. }}$ & $12.42 \pm 0.12^{\mathrm{a}}$ & $3.74 \pm 0.16^{\mathrm{a}}$ \\
\hline PEMF & $7.26 \pm 0.20^{\text {n.s. }}$ & $1.63 \pm 0.07^{\text {n.s. }}$ & $10.81 \pm 0.16^{\mathrm{ab}}$ & $2.60 \pm 0.08^{b c}$ \\
\hline \multicolumn{5}{|c|}{ B. High germination capability } \\
\hline Untreated & $8.16 \pm 0.30^{\text {n.s. }}$ & $2.55 \pm 0.04^{\text {n.s. }}$ & $7.82 \pm 0.16^{b}$ & $2.23 \pm 0.11^{c}$ \\
\hline CAP5 & $8.09 \pm 0.34^{\text {n.s. }}$ & $1.99 \pm 0.05^{\text {n.s. }}$ & $9.73 \pm 0.17^{b}$ & $2.33 \pm 0.14^{c}$ \\
\hline CAP10 & $8.23 \pm 0.36^{\text {n.s. }}$ & $1.75 \pm 0.08^{\text {n.s. }}$ & $10.30 \pm 0.12^{\mathrm{ab}}$ & $3.29 \pm 0.15^{\mathrm{ab}}$ \\
\hline CAP15 & $8.40 \pm 0.08^{\text {n.s. }}$ & $1.97 \pm 0.04^{\text {n.s. }}$ & $12.29 \pm 0.18^{\mathrm{a}}$ & $3.85 \pm 0.15^{\mathrm{a}}$ \\
\hline PEMF & $8.49 \pm 0.38^{\text {n.s. }}$ & $1.84 \pm 0.09^{\text {n.s. }}$ & $8.64 \pm 0.12^{b}$ & $2.69 \pm 0.18^{b c}$ \\
\hline
\end{tabular}

CAP5, CAP10, CAP15: Cold atmospheric Plasma pre-sowing treatment of the maize seeds for 5, 10 and 15 min, respectively PEMF: Pulsed electromagnetic field pre-sowing treatment of the maize seeds for $15 \mathrm{~min}$. Mean value of three replicates \pm standard deviation. Values with different superscripts $(a, b, c)$ in the same column were significantly different as shown by Duncan's multiple range test. ${ }^{\text {n.s. }}$ : not significant.

including their total protein and crude fiber content and maintained mostly their physical properties (color, texture, sphericity, size). This is essential for the design and optimization of the processing equipment including harvesting, handling and preparation for their development in food products (Geeta et al., 2017).

\section{Effect of novel technologies on physicochemical characteristics and functional properties of the harvested corn seeds}

Table 7 presents the effect of different pre-sowing treatments of maize seeds with low and high germination capability on the physicochemical characteristics such as moisture and ash as well as on functional properties including total protein and total crude fiber content of the harvested corn seeds, respectively. There were no significant differences in the moisture and ash content between corn grains from plants pre-treated and from untreated plants for both germination capabilities. The moisture and ash content of corn grains ranged between $7.26-8.60 \%$ and $1.29-2.09 \%$, respectively, for different pre-sowing treatments of maize seeds with low germination capability and between 8.09-
$8.49 \%$ and $1.55-2.55 \%$, respectively, for different pre-sowing treatments of maize seeds with high germination capability. Concerning the maize seeds with low germination capability, by applying CAP pre-sowing treatment for $15 \mathrm{~min}$, the harvested corn grains contained the highest total protein content $(12.42 \%)$ among all the grains of other treatments $(p<0.05)$. The different pre-sowing treatments affected also significantly the total crude fiber content of corn grains; by applying CAP treatment for 10 and $15 \mathrm{~min}$, the crude fiber content of corn grains was positively higher (3.56 and 3.74\%, respectively) than the one obtained by the other treatments $(p<0.05)$. It should be noted that the total protein and crude fiber content of corn grains obtained by CAP treatment for 15 min were approximately $26 \%$ and $29 \%$ higher than those obtained for the control.

Regarding the maize seeds with high germination capability, the different pre-sowing treatments affected significantly the total protein and crude fiber content of corn grains $(p<0.05)$. By applying CAP pre-sowing treatment for $15 \mathrm{~min}$, the corn grains had the highest total protein $(12.29 \%)$ and total crude fiber (3.85\%) content of all the grains of other treatments, except for CAP treatment for $10 \mathrm{~min}(10.30 \%$ and $3.29 \%$, respectively). The total protein and crude fiber content of corn grains obtained by CAP treatment for $15 \mathrm{~min}$ 
were approximately $36 \%$ and $42 \%$ higher than those obtained for the control.

\section{Discussion}

The pre-sowing treatments applied to cereal seeds should result in higher or at least equivalent crop productivity and final product quality compared to the untreated seeds. The results of the present study confirmed that the CAP treatment improved the valuable quality properties (total protein and crude fiber content) of the final crop products (corn grains) and the PEMF treatment produced corn grains with identical quality characteristics with those obtained by the untreated seeds. Previous studies have shown the effect of CAP pre-sowing treatment of cereal seeds as a final agricultural product. He et al. (2016) pretreated three different wheat seeds with CAP for $15 \mathrm{~s}$ and investigated their growth on the field. The final wheat grains harvested from CAP pretreated seeds resulted in improved quality properties such as length, number of grains per spike and total protein content. Moreover, Roy et al. (2018a, b) concluded that by applying CAP as pre-sowing treatment, the final wheat grains presented significant improvement in the thousand-grain weight, total number of grains per spike as well as in the wheat yield. Soluble proteins include significant compounds of many plant enzymes, which affect the plant metabolism and therefore they are key compounds for its growth (Li et al., 2014). It should be mentioned that many studies have shown that CAP pretreatment significantly enhanced the protein content of seedlings compared to the one of the control (Yin et al., 2005; Wu et al., 2007; Li et al., 2014; Li et al., 2015; Li et al., 2016). This could be an explanation about the improved total protein content in harvested corn grains from CAP pretreated seeds of both germination capabilities in the present study. In summary, CAP pre-sowing treatment has the potential to enhance the germination and seedling growth rates of soybean.

The conclusions of the current study regarding the application of pre-sowing treatments such as cold atmospheric plasma (CAP) and pulsed electromagnetic fields (PEMF) on two maize crop types of different (low and high) germination capabilities are summarized in the significant effect of the growth, physiology and crop yield of maize as well as of the quality characteristics of the harvested corn grains. It was noted a positive effect of the CAP and PEMF treatments on the chlorophyll content, the photosynthetic rate, the transpiration rate, the stomatal conductance and the dry weight of maize plants. Also, the yield of the maize was favored by both pre-sowing treatments of seeds with low and high germination capability. The use of CAP treatment caused an increase in the total protein and crude fiber contents in harvested maize grains, with the greatest increase observed upon the application of CAP for $15 \mathrm{~min}$. The results recommended that the CAP and PEMF presowing treatments could be used as alternative ameliorative tools in order to improve maize growth, productivity, yield and quality of the final products. Further studies are needed to investigate the mechanisms of action of CAP and PEMF treatments that enhance seed stimulation, germination and quality.

\section{Materials and methods}

\section{Plant material}

For the two experiments, seeds of the maize hybrid GW 8002 (Spyrou SA, Athens, Greece) from two different harvesting years were used (2018 and 2016). These two lots of seeds were selected because they presented different germination capability. The first was characterized as high, because of the high germination capability and the second was characterized as low because of the low germination capability, respectively. The hybrid GW 8002 is generally characterized as a high performance hybrid, because of high yield and excellent product characteristics.

\section{Cold Atmospheric Plasma (CAP) pre-sowing treatment of maize seeds}

CAP pre-sowing treatment of the maize seeds was performed in a closed rectangular reactor chamber equipped with a Surface Dielectric Barrier Discharge (SDBD) source on the upper side (Dimitrakellis et al., 2020) achieving a homogeneous treatment on the entire seed surface. The SDBD device was powered by $45 \mathrm{kHz}$ sinusoidal AC high voltage at $6 \mathrm{kV}$ peak-to-peak. The sinusoidal voltage signal was created using a signal generator and amplified using sequentially a power amplifier and a high voltage transformer. The efficiency of CAP application on the maize seeds was evaluated at three different processing times (5, 10 and $15 \mathrm{~min})$. After CAP treatment, the seeds were exposed to ambient atmosphere for $24 \mathrm{~h}$ before their sowing on the field.

\section{Pulsed electromagnetic fields (PEMF) pre-sowing treatment of the maize seeds}

The seeds of the maize were treated before planting with a PAPIMI electromagnetic field generator for 30 minutes. This device (PAPIMI) is a pulsed electromagnetic field (PEMF) generator (PAPIMI model 600; Pulse Dynamics, Athens, Greece. Manufacturer characteristics: 35-80 J/pulse energy, $1 \times 10-6$ s wave duration, $35-80 \times 106 \mathrm{~W}$ wave power, amplitude of the order of $12.5 \mathrm{mT}$, rise time $0.1 \mathrm{~ms}$, fall time $10 \mathrm{~ms}$, repetitive frequency of $3 \mathrm{~Hz}$.). PAPIMI has been used for the healing of skin wounds in rats (Milgram et al., 2004; Athanasiou et al., 2007) and in several agricultural studies for different plant species (Efthimiadou et al., 2014, Katsenios et al., 2016). After PEMF treatment, the seeds were exposed to ambient atmosphere for $24 \mathrm{~h}$ before their sowing on the field.

\section{Experimental design}

The experiments had a completely randomized design (CRD) with five treatments and three replications. CAP treatment was applied for 5, 10 and 15 min while PEMF treatment for $30 \mathrm{~min}$. Seeds that were not treated were used as control. The field experiments were established at Oropos $\left(38^{\circ} 18^{\prime} \mathrm{N}, 23^{\circ} 45^{\prime} \mathrm{E}\right.$, Altitude $\left.45 \mathrm{~m}\right)$, in the Prefecture of Attica, Greece. The soil was $\mathrm{CL}$, with $\mathrm{pH} 7.5$ and organic matter 5.5\%. More details for the soil Physical and chemical properties are presented in Table 1 as previously published from authors (Efthimiadou et al., 2020). The sowing was conducted at 21/4/2019. Every plot was consisted of an area of $9 \mathrm{~m}^{2}$, with 4 rows per plot and the space between rows was fixed at $75 \mathrm{~cm}$. Forty seeds were sowed at every plot. The temperature and precipitation during field experiments are presented in Table 2 .

\section{Germination and growth measurements}

For the measurement of germination percentage, the precise number of the plants emerged has been counted 
and then divided by the number of the seeds that have been sowed, in order to calculate the percentage. The measurements of dry weight, chlorophyll content, photosynthetic rate, transpiration rate and stomatal conductance were conducted at 52, 72 and 88 days after sowing (DAS). The measurement of dry weight (g per plant) it was taken after the samples were oven dried at $70^{\circ} \mathrm{C}$ for three days in a precision balance. For the determination of the chlorophyll $(\mu \mathrm{g} / \mathrm{cm} 2)$ content, a portable chlorophyll meter (SPAD) was used. Photosynthetic rate $\left(\mu \mathrm{mol} \mathrm{CO} 2 \mathrm{~m}^{-2}\right.$ $\left.\mathrm{s}^{-1}\right)$, transpiration rate $\left(\mathrm{mmol} \mathrm{H}_{2} \mathrm{O} \mathrm{m} \mathrm{m}^{-2} \mathrm{~s}^{-1}\right)$ and stomatal conductance $\left(\mathrm{mol} \mathrm{m}^{-2} \mathrm{~s}^{-1}\right)$ were conducted on days with clear sky without any clouds, on fully expanded leaves, during midday using a LCi Leaf Chamber Analysis System (ADC, Bioscientific, Hoddesdon, UK). The yield measurement was conducted at 20/8/2019 (122 DAS).

\section{Physicochemical properties of harvested corn seeds}

The effect of the different pre-sowing treatments on the quality of the corn seeds harvested from two different maize seeds with low and high germination capability, respectively, was investigated. The primary physicochemical characteristics including color, texture, sphericity, size, ash, total protein and total crude content were determined. The corn seeds were harvested and dried in the shade following the farming practices. The corn seeds had initial moisture content of approximately $15 \%(\mathrm{w} / \mathrm{w}$, dry basis) and of $8 \%$ ( $w / w$, dry basis) after the drying procedure.

The color of the corn seeds was measured using Minolta Spectrophotometer (CR-300, Minolta Company, Chuo-Ku, Osaka, Japan). The lightness or brightness of the samples was indicated by the $\mathrm{L}$ value where $0-100$ represents darkness to lightness color. Redness or greenness of the corn seeds or flours was indicated by the a-value, where a high positive a value indicates more red color. The $b$-value indicates the degree of the yellow-blue color, with a higher positive $b$ value indicating more yellowness.

Texture analysis was conducted by using a HD-Plus texture analyzer (Stable Micro Systems Ltd., UK) and the Texture Expert Exceed Software for the data analysis. The determination of the textural characteristics of corn seeds was carried out by a puncture probe of $5 \mathrm{~mm}$ diameter. Probe speeds of $1 \mathrm{~mm} / \mathrm{s}$ during the test, $2 \mathrm{~mm} / \mathrm{s}$ for pre- test and $10 \mathrm{~mm} / \mathrm{s}$ for post- test were used throughout the study. All the measurements were performed at $25 \pm 1{ }^{\circ} \mathrm{C}$ and the hardness of the corn seeds was determined.

The tri-axial dimensions including length, width and thickness of the corn seed were measured by a digital raider micrometer screw gauge to calculate its geometric mean diameter (size) and the sphericity by the following formula:

$$
\begin{gathered}
\text { Size }=(a \times b \times c)^{1 / 3} \\
\text { Sphericity }=\frac{(a \times b \times c)^{1 / 3}}{a}
\end{gathered}
$$

where, $a=$ length $(\mathrm{mm}) ; b=$ width $(\mathrm{mm}) \mathrm{c}=$ thickness $(\mathrm{mm})$ The corn seeds were grinded using a grinding mill. The ground kernels were used for the determination of the moisture, the ash, the total protein, and the total crude fiber content. Total protein content analysis of corn flours was performed by applying the Kjeldahl method (IDF 2008), using a Kjeldahl rapid distillation unit (Protein Nitrogen Distiller DNP-1500-MP, RAYPA, Spain). Moisture, ash and crude fiber content of corn flours were determined according to AOAC Official Method 925.09, 923.03 and 984.04 (Weende Method), respectively.

\section{Statistical analysis}

A one-way analysis of variance (ANOVA) was used to evaluate the effect of CAP and PEMF pre-sowing treatment on the cultivation and quality responses of two maize types. The experimental data were analyzed using IBM SPSS software ver. 24 (IBM Corp., Armonk, N.Y., USA). The comparisons of means were calculated using Duncan test at the $5 \%$ level of significance $(p<0.05)$.

\section{References}

Alan O, Kinaci G, Kinaci E, Basciftci ZB, Sonmez K, Evrenosoglu Y, Kutlu I (2014) Kernel quality of some sweet corn varieties in relation to processing. Not Bot Horti Agrobo. 42:414-419.

Araújo SS, Paparella S, Dondi D, Bentivoglio A, Carbonera D, Balestrazzi A (2016) Physical methods for seed invigoration: advantages and challenges in deed technology. Front Plant Sci. 7:646.

Atere AO, Olalusi AP, Olukunle OJ (2016) Physical properties of some maize varieties. J Multidiscip Eng Sci Technol. 3:38743880.

Athanasiou A, Karkambounas S, Batistatou A, Lykoudis E, Katsaraki A, Kartsiouni T, Papalois A, Evangelou A (2007) The effect of pulsed electromagnetic fields on secondary skin wound healing: an experimental study. Bioelectromagnetics. 28:362-368.

Bilalis DJ, Katsenios N, Efthimiadou A, Karkanis A (2012) Pulsed electromagnetic field: An organic compatible method to promote plant growth and yield in two corn types. Electromagn Biol Med. 31:333-343.

Cakmak T, Dumlupinar R, Erdal S (2010) Acceleration of germination and early growth of wheat and bean seedlings grown under various magnetic field and osmotic conditions. Bioelectromagnetics. 31:120-129.

Carbonell MV, Martínez E, Amaya JM (2000) Stimulation of germination in rice (Oryza sativa L.) by a static magnetic field. Electromagn Biol Med. 19(1):121-128.

De Groot GJJB, Hundt A, Murphy AB, Bange MP, Mai-Prochnow $A$ (2018) Cold plasma treatment for cotton seed germination improvement. Sci Rep 8:1-10.

Dimitrakellis P, Giannoglou M, Zeniou A, Katsaros G, Gogolides E (2020) Food container employing a cold atmospheric plasma source for prolonged preservation of plant and animal origin food. MethodsX. Under review MEX-S-20-00728

Dobrin D, Magureanu M, Mandache NB, Ionita MD (2015) The effect of non-thermal plasma treatment on wheat germination and early growth. Innov Food Sci Emerg Technol. 29:255-260.

Efthimiadou A, Katsenios N, Karkanis A, Papastylianou P,Triantafyllidis V, Travlos I, Bilalis JD (2014) Effects of presowing pulsed electromagnetic treatment of tomato seed on growth, yield, and lycopene content. Sci World J. 369745.

Efthimiadou, A., Katsenios, N., Chanioti, S. et al. Effect of foliar and soil application of plant growth promoting bacteria on growth, physiology, yield and seed quality of maize under Mediterranean conditions. Sci Rep 10, 21060 (2020). https://doi.org/10.1038/s41598-020-78034-6

Fischer G, Tausz M, Kock M (2004) Effects of weak 16 2/3 Hz magnetic fields on growth parameters of young sunflower and wheat seedlings. Bioelectromagnetics. 25:638-641.

Flórez M, Carbonell MV, Martínez E (2007) Exposure of maize seeds to stationary magnetic fields: Effects on germination and early growth. Environ Exp Bot. 59(1):68-75.

Geeta HP, Palanimuthu V, Srinivas G (2017) Study of some physico-chemical properties of sweet corn. Int J Agric Sci Res. 7:277-286.

He Z, Wang Y, Wang J, Tang C (2016) Influence of cold plasma treatment on ear characters and group quality of wheat. ASABE Annual International Meeting. 162461144. 
Javed N, Ashraf M, Akram Nudrat A, Al-Qurainy F (2011) Alleviation of adverse effects of drought stress on growth and some potential physiological attributes in maize (Zea mays L.) by seed electromagnetic treatment. Photochem Photobiol. 87:1354-1362.

Jiang J, He X, Li L, Li J, Shao H, Xu Q, Ye R, Dong Y (2014) Effect of cold plasma treatment on seed germination and growth of wheat. Plasma Sci Technol. 16:54-58.

Kataria S, Baghel L, Guruprasad KN (2017) Pre-treatment of seeds with static magnetic field improves germination and early growth characteristics under salt stress in maize and soybean. Biocatal Agric Biotechnol. 10:83-90.

Katsenios N, Bilalis D, Efthimiadou A, Aivalakis G, Nikolopoulou AE, Karkanis A, Travlos I (2016) Role of pulsed electromagnetic field on enzyme activity, germination, plant growth and yield of durum wheat. Biocatal Agric Biotechnol. 6:152-158.

Kumar R, Thakur AK, Vikram A, Vaid A, Rane R (2019) Effect of cold plasma treatment of seeds on quality of seed crop of okra. Int J Econ Plants. 6:073-077.

Leelapriya T, Dhilip KS, Sanker Narayan PV (2003). Effect of weak sinusoidal magnetic field on germination and yield of cotton (Gossypium spp.). Electromag Biol Med. 22:117-125.

Li L, Jiang J, Li J, Shen M, He X, Shao H, Dong Y (2014) Effects of cold plasma treatment on seed germination and seedling growth of soybean. Sci Rep. 4:1-7.

Li L, Li J, Shen M, Zhang C, Dong Y (2015) Cold plasma treatment enhances oilseed rape seed germination under drought stress. Sci. Rep. 5:1-10.

Li L, Li J, Shen M, Hou J, Shao H, Dong Y, Jiang J (2016) Improving seed germination and peanut yields by cold plasma treatment. Plasma Sci Technol. 18:1027-1033.

Lo Porto C, Sergio L, Boari F, Logrieco A, Cantore V (2019) Cold plasma pretreatment improves the germination of wild asparagus (Asparagus acutifolius L.) seeds. Sci Hortic. 256:108554.

Lotfy K Effects of Cold Atmospheric Plasma Jet Treatment on the Seed Germination and Enhancement Growth of Watermelon. Open J. Appl. Sci. 07:705-719.

Meng Y, Qu G, Wang T (2017) Enhancement of germination and seedling growth of wheat seed using dielectric barrier discharge plasma with various gas sources. Plasma Chem Plasma Process. 37:1105-1119.

Milgram J, Shahar R, Levin-Harrus T, Kass P (2004) The effect of short high in tensity magnetic field pulses on the healing of skin wounds in rat. Bioelectromagnetics. 25: 271-277.

Patel P, Narayanaswamy GK, Kataria S, Baghel L (2017) Involvement of nitric oxide in enhanced germination and seedling growth of magnetoprimed maize seeds. Plant Signal Behav. 12(12):e1293217.

Pérez-Pizá MC, Prevosto L, Grijalba PE, Zilli CG, Cejas E, Mancinelli B, Balestrasse KB (2019) Improvement of growth and yield of soybean plants through the application of nonthermal plasmas to seeds with different health status. Heliyon 5:e01495.

Pietruszewski S (1996) Effects of magnetic biostimulation of wheat seeds on germination, yield and proteins. Int Agrophys. 10(1):51-55.

Pietruszewski S, Kania K (2010) Effect of magnetic field on germination and yield of wheat. Int Agrophys. 24:297-302.
Puač N, Škoro N, Spasić K, Živković S, Milutinović M, Malović G, Petrović ZL (2018) Activity of catalase enzyme in Paulownia tomentosa seeds during the process of germination after treatments with low pressure plasma and plasma activated water. Plasma Process Polym. 15(2):1700082.

Racuciu M, Creanga D, Horga I (2008) Plant growth under static magnetic field influence. Rom J Phys. 53(1-2):331-336.

Radhakrishnan R, Kumari BR (2012). Pulsed magnetic field: A contemporary approach offers to enhance plant growth and yield of soybean. Plant Physiol Bioch. 51:139-144.

Roy NC, Hasan MM, Kabir AH, Reza MA, Talukder MR, Chowdhury AN (2018a) Atmospheric pressure gliding arc discharge plasma treatments for improving germination, growth and yield of wheat. Plasma Sci Technol. 20:115501.

Roy NC, Hasan MM, Talukder MR, Hossain MD, Chowdhury AN (2018b) Prospective applications of low frequency glow discharge plasmas on enhanced germination, growth and yield of wheat. Plasma Chem Plasma Process. 38:13-28.

Scholtz V, Šerá B, Khun J, Šerý M, Julák J (2019) Effects of nonthermal plasma on wheat grains and products. J Food Qual. 2019(1):1-10.

Sera B, Sery M, Gavril B, Gajdova I (2017) Seed germination and early growth responses to seed pre-treatment by non-thermal plasma in hemp cultivars (Cannabis sativa L.). Plasma Chem Plasma Process. 37:207-221.

Šerá B, Špatenka P, Šerý M, Vrchotová N, Hrušková I (2010) Influence of plasma treatment on wheat and oat germination and early growth. IEEE Trans Plasma Sci. 38:2963-2968.

Sivachandiran L, Khacef A (2017) Enhanced seed germination and plant growth by atmospheric pressure cold air plasma: combined effect of seed and water treatment. RSC Adv. 7:1822-1832.

Shabrangi A, Majd A, Sheidai M (2010) Comparing effects of extremely low frequency electromagnetic fields on the biomass weight of $\mathrm{C} 3$ and C4 plants in early vegetative growth. Paper presented at the progress in electromagnetics research symposium, Cambridge, USA, July 2010.

Thirumdas R, Kothakota A, Kiran K, Pandiselvam R, Prakash V (2017) Exploitation of cold plasma technology in agriculture. Adv Res. 12:1-7.

USDA, 2020. World Corn Production 2019/2020 URL http://www.worldagriculturalproduction.com/crops/corn.asp $x$

Vashisth A, Joshi DK (2017) Growth characteristics of maize seeds exposed to magnetic field. Bioelectromagnetics. 38:151157.

Wu ZH, Chi LH, Bian SF, Xu KZ (2007) Effects of plasma treatment on maize seeding resistance. J Maize Sci. 15:111113.

Yenge GB, Kad VP, Nalawade SM (2018) Physical properties of maize (Zea mays L.) grain. J Krishi Vigyan. 7:125-128.

Yin MQ, Huang MJ, Ma BZ, Ma TC (2005) Stimulating effects of seed treatment bymagnetized plasma on tomato growth and yield. Plasma Sci Technol. 7:3143-3147.

Zahoranová A, Hoppanová L, Šimončicová J, Tučeková Z, Medvecká V, Hudecová D, Kaliňáková $B$, Kováčik $D$, Černák M (2018) Effect of cold atmospheric pressure plasma on maize seeds: Enhancement of seedlings growth and surface microorganisms inactivation. Plasma Chem Plasma Process. 38:969-988. 